\title{
Gastro-oesophageal reflux disease symptoms and associated risk factors among medical students, Saudi Arabia
}

This article was published in the following Dove Press journal: International Journal of General Medicine

Mohamed Magdi Attal,2

Mohamed Hisham Sayed ${ }^{3,4}$

Mohamed A Zayed ${ }^{5,6}$

Sultan A Alsulami ${ }^{1}$

Ahmed T Al-Maghrabi'

Abdulhfeez Y Kelantan'

'Department of Medicine, Rabigh Faculty of Medicine, King Abdulaziz University, Jeddah, Kingdom of Saudi Arabia; ${ }^{2}$ Department of Hepatology,

Gastroenterology and Infectious

Diseases, Faculty of Medicine, Benha

University, Benha, Egypt; ${ }^{3}$ Department of Pediatrics, Rabigh Faculty of Medicine,

King Abdulaziz University, Jeddah, Kingdom of Saudi Arabia; ${ }^{4}$ Department of Pediatrics, Faculty of Medicine, Cairo University, Cairo, Egypt; ${ }^{5}$ Department of Physiology, Rabigh Faculty of Medicine, King Abdulaziz University, Jeddah,

Kingdom of Saudi Arabia; ${ }^{6}$ Department of Physiology, Faculty of Medicine, Menoufia University, Shibīn Al Koum, Egypt
Correspondence: Mohamed A Zayed Faculty of Medicine in Rabigh, King Abdulaziz University, building 13, P.O. BOX 80205, Jeddah 21589, Saudi Arabia Tel +966562603213

Fax +966 I26400000

Email mazayed@kau.edu.sa
Background and aims: Gastro-oesophageal reflux disease (GERD) is a common gastrointestinal disease worldwide that is associated with impaired quality of life and higher risk of complications. The identification of risk factors is necessary for preventive measures. The aim of this study is to evaluate the prevalence of GERD symptoms as well as its relation to body mass index (BMI) and other risk factors among medical students of Jeddah and Rabigh branches, King Abdul-Aziz University, Saudi Arabia.

Subjects and methods: A cross-sectional study was conducted at the Faculty of Medicine in Rabigh, King Abdul-Aziz University, Saudi Arabia. The study included 197 medical students from Rabigh and Jeddah branches of the university. The study employed a Gastroesophageal Reflux Disease Questionnaire which is derived from a self-administered validated GERD questionnaire (GerdQ).

Results: The prevalence of GERD symptoms was $25.9 \%$. The most frequent symptoms were regurgitation and burning sensation. High BMI, family history, energy drinks and fried food were found to be statistically significant risk factors $(p<0.05)$ by univariate analysis. However, the logistic regression for the prediction of GERD symptoms among medical students showed that only family history had a significant correlation $(p<0.05)$.

Conclusion: GERD symptoms were common in medical students of King Abdulaziz University, Saudi Arabia. Family history was found to be a significant predictor of GERD symptoms. Effective educational strategies for groups with significant risk factors of GERD need to be implemented.

Keywords: GERD, risk factors, medical students

\section{Introduction}

Gastroesophageal reflux disease (GERD) is a medical problem arising from the return of contents of the stomach to the esophagus leading to disturbing symptoms. The characteristic typical symptoms are heartburn and acid regurgitation. The prevalence in adults ranges from $30 \%$ in some Western countries to $<10 \%$ in East Asian countries. ${ }^{1}$ It is associated with impaired quality of $\operatorname{life}^{2}$ and a higher risk of oesophageal carcinoma. ${ }^{3}$ The pathophysiology of GERD included defects at the gastroesophageal junction, transient relaxations of the lower esophageal sphincter and formation of hiatal hernia. ${ }^{4-6}$ In Saudi Arabia population, the prevalence of GERD varies from $28.7 \%$ to $45.4 \%$ based on two different studies. ${ }^{7,8}$

On the other hand, overweight, defined according to the World Health Organization classification as body mass index (BMI) of $\geq 25 \mathrm{~kg} / \mathrm{m}^{2,9}$ is associated 
with reduced health-related quality of life, as well as several chronic diseases. ${ }^{10}$ So much so, it is considered as an important risk for the development of GERD. Moreover, the prevalence of GERD and obesity have increased significantly over the past 40 years in Western populations, suggesting a link between these two disorders. ${ }^{11}$ So, it is worthy to check the relation between GERD and BMI. ${ }^{12}$ Similarly, such relationship will be checked with other risk factors.

\section{Subjects and methods}

A cross-sectional study was conducted at the Faculty of Medicine, King Abdulaziz University, Saudi Arabia. The study included (197) male medical students from Rabigh and Jeddah branches. Verbal informed consent was obtained from medical students who volunteered to share in this study according to the regulations of Rabigh research ethics committee. Institutional review board of King Abdulaziz University approved this verbal consent of participants. The study included using a questionnaire which included two parts. The first part was the GerdQ Gastroesophageal Reflux Disease Questionnaire (GerdQ). ${ }^{13}$ The questionnaire consists of questions that depend on the type and frequency of symptoms experienced by the students. Respondents who get a score of 8 or more have a higher possibility to have GERD, while those who get $<8$ have low or no possibility to have GERD. The GERD questionnaire has a sensitivity of $65 \%$ and a specificity of $71 \%$ for GERD diagnosis. ${ }^{13}$ The second part includes questions about the risk factors of GERD, such as BMI, coffee, tea, and chocolate ingestion, energetic drinks, soft drinks, fried food, sports activities, smoking, and family history. Further, we measured students' height and weight to determine the BMI.

Statistical analysis was performed using SPSS (version 24) software. Data were summarized as mean and SD. All " $p$ " values at $95 \%$ CIs were calculated and $p<0.05$ was considered to be statistically significant.

The study proposal was approved by Rabigh research ethics committee, King Abdulaziz University, Saudi Arabia, date 24/1/2018, ethical approval no. FMR-0439-H.

\section{Results}

Our study included 197 students of Medical College at KAU which consisted of 118 (59.9\%) of Rabigh branch students and $79(40.1 \%)$ of Jeddah branch students. Figure 1 shows that the prevalence of GERD is $25.9 \% ; 19.3 \%$ of them had a

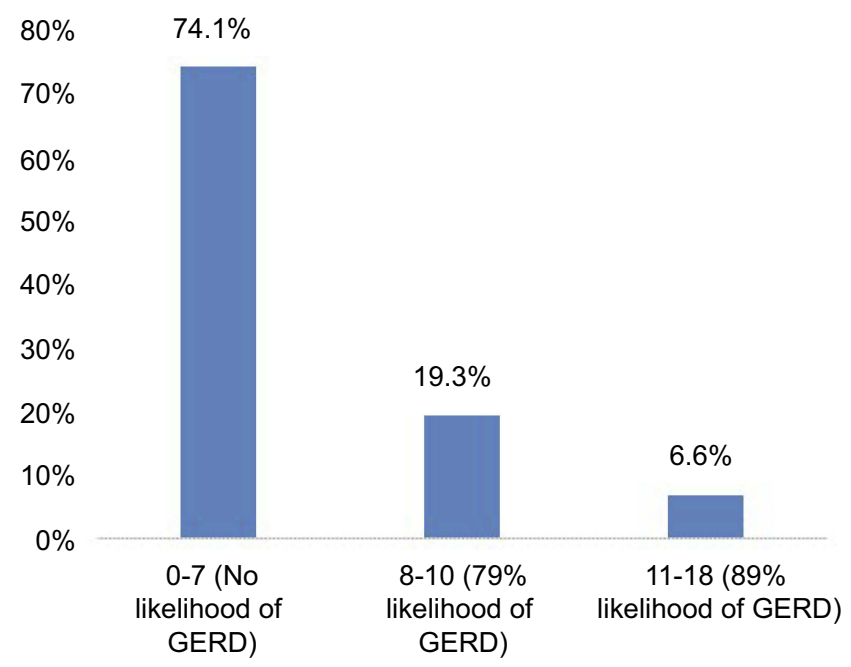

Figure I Classification of participants according to GERD score.

score of $8-10$ of GerdQ (79\% likelihood of GERD), and $6.6 \%$ had a score of $11-18$ of GerdQ ( $89 \%$ likelihood of GERD).

Classification of participants according to body weight is shown in Figure 2. The GerdQ score in students' groups according to their BMI is shown in Figure 3.

The most common symptoms whether mild (once/ week), moderate (2-3/week) or severe (4-7/week) were regurgitation (41.2\%), and burning sensation (31.4\%). However, if severity of symptoms was considered, the most common were burning sensation $(8.1 \%)$, followed by regurgitation (6.1\%) (Table 1).

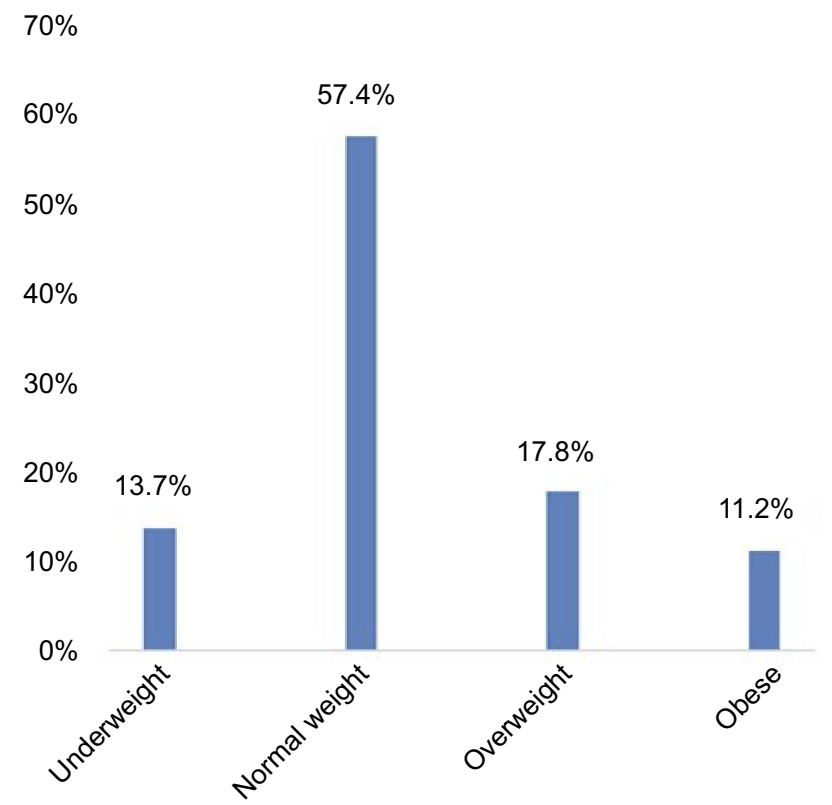

Figure 2 Classification of participants according to body weight. 


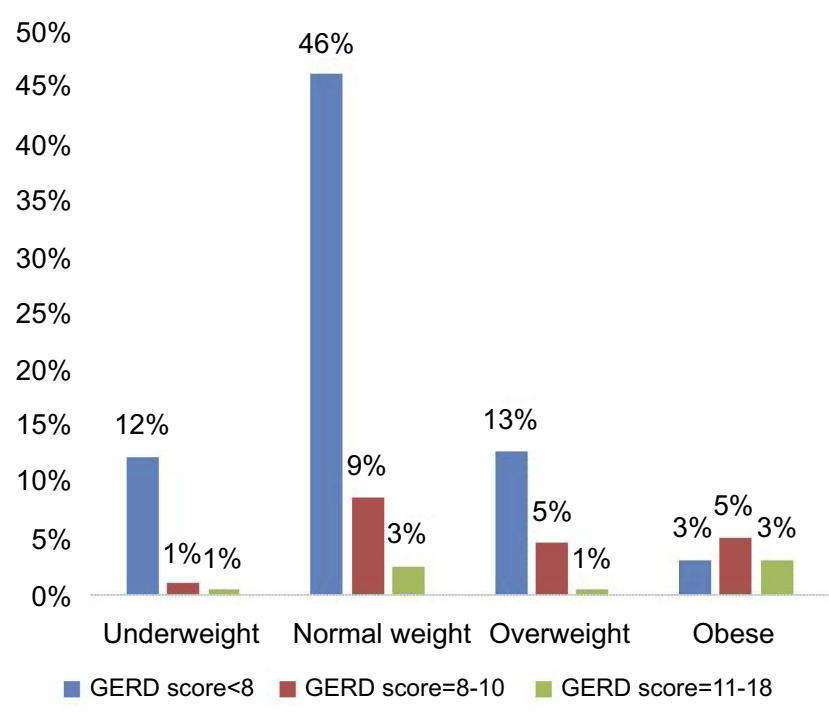

Figure 3 The GerdQ score in participants according to their BMI.

The association between risk factors and students with positive ( $8-18$ score) and negative ( $0-7$ score) GERD symptoms is shown in Table 2. BMI, family history, energy drinks

Table I The frequency of GERD symptoms among the participants

\begin{tabular}{|c|c|c|c|}
\hline & & No & $\%$ \\
\hline \multirow{4}{*}{ Burning sensation } & None & 135 & $68.5 \%$ \\
\hline & Once & 40 & $20.3 \%$ \\
\hline & $2-3 /$ week & 6 & $3.0 \%$ \\
\hline & 4-7/week & 16 & $8.1 \%$ \\
\hline \multirow[t]{4}{*}{ Regurgitation } & None & 116 & $58.9 \%$ \\
\hline & Once & 60 & $30.5 \%$ \\
\hline & $2-3 /$ week & 9 & $4.6 \%$ \\
\hline & 4-7/week & 12 & $6.1 \%$ \\
\hline \multirow[t]{4}{*}{ Chest pain } & None & 156 & $79.2 \%$ \\
\hline & Once & 29 & $14.7 \%$ \\
\hline & 2-3/week & 10 & $5.1 \%$ \\
\hline & 4-7/week & 2 & $1.0 \%$ \\
\hline \multirow[t]{4}{*}{ Nausea } & None & 143 & $72.6 \%$ \\
\hline & Once & 38 & $19.3 \%$ \\
\hline & 2-3/week & 12 & $6.1 \%$ \\
\hline & 4-7/week & 4 & $2.0 \%$ \\
\hline \multirow[t]{4}{*}{ Difficulty sleep } & None & 161 & $81.7 \%$ \\
\hline & Once & 19 & $9.6 \%$ \\
\hline & $2-3 /$ week & 9 & $4.6 \%$ \\
\hline & 4-7/week & 8 & $4.1 \%$ \\
\hline \multirow[t]{4}{*}{ Over counter medications } & None & 164 & $83.2 \%$ \\
\hline & Once & 23 & $11.7 \%$ \\
\hline & 2-3/week & 6 & $3.0 \%$ \\
\hline & 4-7/week & 4 & $2.0 \%$ \\
\hline
\end{tabular}

and fried food were found to be statistically significant risk factors $(p<0.05)$ in students who had the likelihood of GERD. However, there was no such relation between smoking and GERD score. The logistic regression for the prediction of GERD among medical students showed that only the family history had a significant correlation; $p<0.05$ (Table 3).

\section{Discussion}

GERD is a common gastrointestinal disease that is associated with variable complications. This study aimed at evaluation of the prevalence of GERD symptoms and associated risk factors among a unique population. The study employed a well-validated GERD score (GerdQ).

Worldwide, the prevalence of GERD varies for unknown reasons. In a systematic review, the prevalence of GERD ranged from $18-27 \%$ in North America, $8-25 \%$ in Europe, $2-7 \%$ in East Asia and $8-33 \%$ in the Middle East. ${ }^{1}$ One study done among Tunisian primary care population found a prevalence of $24 \% .{ }^{14}$ In another study done among hospital employees in North India, GERD prevalence was found to be $16.2 \%{ }^{15}$ The reported prevalence of GERD in medical students from Syria and Iran was $14.8 \%$ and $21.2 \%$, respectively. ${ }^{16,17}$

Yet, in Asia, the prevalence of GERD has been increasing gradually, which may be attributed to the rapidly developing economy and consequent change in diet and lifestyle taking place in many Asian countries. ${ }^{18}$ In Saudi Arabia population, the prevalence of GERD varies from $28.7 \%$ to $45.4 \%$ based on two different studies. ${ }^{7,8}$

In the current study, the prevalence of GERD symptoms in medical students was $25.9 \%$. One more study on medical students in a medical college in India found a prevalence of $25 \% .{ }^{19}$ However, another study done among medical students in Chennai, South India has shown a prevalence of GERD of $14.4 \%{ }^{20}$ The relatively high prevalence in the current study can be attributed to a rather luxury lifestyle that involves diet preferences and sedentary life habits.

Obesity is a well-known risk factor for GERD in both Asian and Western countries. Large epidemiological studies have demonstrated that obesity is an important risk factor of GERD. ${ }^{21,22}$ Further, a linear increase of reflux symptoms for each BMI category was found. ${ }^{23}$

In the current study, univariate analysis had shown that GERD score was significantly associated with BMI, family history, energetic drinks and fried food. Likewise, higher BMI, use of NSAID or alcohol, inadequate sleep, sleeping within $1 \mathrm{hr}$ of taking dinner, missing breakfast regularly and quick eating in final year medical students were significantly associated with GERD $(p<0.05)$ in one study. ${ }^{19}$ This finding 
Table 2 Risk factors of GERD symptoms in participants

\begin{tabular}{|c|c|c|c|c|c|c|}
\hline \multicolumn{2}{|l|}{ Characteristics } & \multicolumn{4}{|c|}{ Score groups } & \multirow{3}{*}{$p$-value } \\
\hline & & \multicolumn{2}{|c|}{ Negative } & \multicolumn{2}{|c|}{ Positive } & \\
\hline & & $\mathbf{n}$ & $\%$ & $\mathbf{n}$ & $\%$ & \\
\hline BMI & $\begin{array}{l}\text { Underweight } \\
\text { Normal weight } \\
\text { Overweight } \\
\text { Obese }\end{array}$ & $\begin{array}{l}24 \\
91 \\
25 \\
6\end{array}$ & $\begin{array}{l}88.9 \% \\
80.5 \% \\
71.4 \% \\
27.3 \%\end{array}$ & $\begin{array}{l}3 \\
22 \\
10 \\
16\end{array}$ & $\begin{array}{l}11.1 \% \\
19.5 \% \\
28.6 \% \\
72.7 \%\end{array}$ & 0.000 \\
\hline Coffee, tea, chocolate & $\begin{array}{l}\text { None } \\
\text { Once/day } \\
2-3 / \text { day } \\
\text { More than 3/day }\end{array}$ & $\begin{array}{l}41 \\
61 \\
34 \\
46\end{array}$ & $\begin{array}{l}91.1 \% \\
98.4 \% \\
89.5 \% \\
88.5 \%\end{array}$ & $\begin{array}{l}4 \\
1 \\
4 \\
6\end{array}$ & $\begin{array}{l}2.2 \% \\
1.6 \% \\
10.5 \% \\
11.5 \%\end{array}$ & 0.18 \\
\hline Energetic drinks & $\begin{array}{l}\text { None } \\
\text { Once/day } \\
2-3 / \text { day } \\
\text { More than 3/day }\end{array}$ & $\begin{array}{l}108 \\
49 \\
15 \\
10\end{array}$ & $\begin{array}{l}94.7 \% \\
92.5 \% \\
75.0 \% \\
100.0 \%\end{array}$ & $\begin{array}{l}6 \\
4 \\
5 \\
0\end{array}$ & $\begin{array}{l}5.3 \% \\
7.5 \% \\
25.0 \% \\
0.0 \%\end{array}$ & 0.01 \\
\hline Soft drinks & $\begin{array}{l}\text { None } \\
\text { Once/day } \\
2-3 / \text { day } \\
\text { More than 3/day }\end{array}$ & $\begin{array}{l}51 \\
64 \\
38 \\
29\end{array}$ & $\begin{array}{l}98.1 \% \\
92.8 \% \\
92.7 \% \\
82.9 \%\end{array}$ & $\begin{array}{l}1 \\
5 \\
3 \\
6\end{array}$ & $\begin{array}{l}1.9 \% \\
7.2 \% \\
7.3 \% \\
17.1 \%\end{array}$ & 0.07 \\
\hline Fried food & $\begin{array}{l}\text { None } \\
\text { Once/day } \\
2-3 / \text { day } \\
\text { More than 3/day }\end{array}$ & $\begin{array}{l}20 \\
78 \\
55 \\
29\end{array}$ & $\begin{array}{l}100.0 \% \\
95.1 \% \\
93.2 \% \\
80.6 \%\end{array}$ & $\begin{array}{l}0 \\
4 \\
4 \\
7\end{array}$ & $\begin{array}{l}0.0 \% \\
4.9 \% \\
6.8 \% \\
19.4 \%\end{array}$ & 0.02 \\
\hline Smoke & $\begin{array}{l}\text { No } \\
\text { Yes }\end{array}$ & $\begin{array}{l}135 \\
47\end{array}$ & $\begin{array}{l}94.4 \% \\
87.0 \%\end{array}$ & $\begin{array}{l}8 \\
7\end{array}$ & $\begin{array}{l}5.6 \% \\
13.0 \%\end{array}$ & 0.08 \\
\hline Family history & $\begin{array}{l}\text { No } \\
\text { Yes }\end{array}$ & $\begin{array}{l}106 \\
75\end{array}$ & $\begin{array}{l}96.4 \% \\
87.2 \%\end{array}$ & $\begin{array}{l}4 \\
11\end{array}$ & $\begin{array}{l}3.6 \% \\
12.8 \%\end{array}$ & 0.01 \\
\hline Sport activities & $\begin{array}{l}\text { No } \\
\text { Yes }\end{array}$ & $\begin{array}{l}59 \\
84\end{array}$ & $\begin{array}{l}68.6 \% \\
78.5 \%\end{array}$ & $\begin{array}{l}27 \\
23\end{array}$ & $\begin{array}{l}31.4 \% \\
21.5 \%\end{array}$ & 0.54 \\
\hline
\end{tabular}

was not confirmed by other researchers; as no relationship between BMI and gastro-oesophageal reflux symptoms was found in a Swedish population-based study. ${ }^{24}$ On the other hand, the relationship between physical activity and GERD was found not significant in the current study. However, some studies revealed that regular physical exercise is associated with a decreased risk of symptoms of reflux. ${ }^{25}$ Also, the association between smoking and GERD was not found to be significant in this study. Yet, the reflux symptoms were found increased during smoking in one study. ${ }^{26}$

Furthermore, the impact of drinks and food items in the induction of GERD symptoms is not clear. ${ }^{27}$ Similar to our results, tea and coffee were not associated with symptoms of GERD, ${ }^{25,27}$ while in another study, coffee increased symptoms of GERD. ${ }^{28}$ The decrease of oesophageal $\mathrm{pH}$ by soft drinks could induce symptoms of GERD, which could clarify the relation present in this study between GERD and energetic drinks. Moreover, the ingestion of fast food is a possible causal risk factor for reflux of acid. ${ }^{29,30}$ Similarly, in this study, a significant relation was found between fried food and symptoms of GERD ( $p$-value $\leq 0.05$ ).

Interestingly, symptoms of GERD were associated with symptoms of reflux in the patient near relatives or a close family member. ${ }^{31}$ Some studies concluded the increased symptoms of GERD in those with a positive family history. ${ }^{32,33}$ Our data were similar to such results. According to some studies, there was evidence of a genetic determinant of GERD. ${ }^{34,35}$ Genetic factors seem to have an important role in GERDrelated disorders. This was verified through studies on twins. Multiple single-nucleotide polymorphisms have been 
Table 3 The logistic regression for the prediction of GERD among medical students

\begin{tabular}{|l|l|l|l|l|l|}
\hline \multirow{2}{*}{ Model } & \multicolumn{2}{|l|}{ Unstandardized coefficients } & Standardized coefficients & T & \\
\cline { 2 - 5 } & B & Std. error & Beta & \\
\hline Energetic drinks & 0.000 & 0.035 & 0.001 & 0.009 & 0.993 \\
Fried food & 0.072 & 0.043 & 0.164 & 1.694 & 0.092 \\
Family history & 0.124 & 0.057 & 0.155 & 2.179 & 0.031 \\
BMI & 0.023 & 0.035 & 0.048 & 0.676 & 0.500 \\
\hline
\end{tabular}

proposed in genome-wide association studies as potential factors in the appearance of reflux disease. ${ }^{36}$ Also, a relation between gene-encoding collagen type III alpha I and symptoms of reflux was detected. ${ }^{37}$ Moreover, it is to be noted that family members share the same environmental factors including dietary habits.

The limitations of this study included a relatively small sample size. These results reflect the high prevalence of GERD symptoms but cannot be applied to the entire Saudi population as the study was conducted in a governmental medical college. Moreover, confirmatory diagnostic tools including upper endoscopy were not employed in this study. Further studies are needed to validate these results and to explore the potential causes for such a high prevalence, as the public health implications of such disease are great and affect the well-being of a large segment of the community. Also, the group with severe GERD symptoms and/or positive family history are to be thoroughly investigated and followed up.

\section{Conclusion}

GERD symptoms are common in medical students of King Abdulaziz University, Saudi Arabia. In general, the most common symptoms were regurgitation and burning sensation, while, if severity of symptoms was considered, the most common were burning sensation, followed by regurgitation, and chest pain. Family history was found to be a significant predictor of GERD symptoms. Effective educational strategies for groups with significant risk factors of GERD need to be implemented.

\section{Disclosure}

The authors report no conflicts of interest in this work.

\section{References}

1. El-Serag HB, Sweet S, Winchester CC, et al. Update on the epidemiology of gastro-oesophageal reflux disease: a systematic review. Gut. 2014;63:871-880. doi:10.1136/gutjnl-2012-304269
2. Ronkainen J, Aro P, Storskrubb T, et al. Gastro-oesophageal reflux symptoms and health-related quality of life in the adult general population-the kalixanda study. Aliment Pharmacol Ther. 2006;23:1725-1733. doi:10.1111/j.1365-2036.2006.02952.x

3. Lagergren J, Bergstrom R, Lindgren A, et al. Symptomatic gastroesophageal reflux as a risk factor for esophageal adenocarcinoma. $N$ Engl J Med. 1999;340:825-831. doi:10.1056/NEJM199905133401909

4. Mittal RK, Balaban DH. The esophagogastric junction. $N$ Engl $J$ Med. 1997;336:924-932. doi:10.1056/NEJM199703273361306

5. Hershcovici T, Mashimo H, Fass R. The lower esophagealsphincter. Neurogastroenterol Motil. 2011;23:819-830. doi:10.1111/j.13652982.2011.01738.x

6. Kessing BF, Conchillo JM, Bredenoord AJ, Smout AJPM, Masclee AAM. Review article: the clinical relevance of transient lower oesophageal sphincter relaxations in gastro-oesophageal reflux disease. Aliment Pharmacol Ther. 2011;33:650-661. doi:10.1111/apt.2011.33. issue-6

7. Alsuwat OB, Alzahrani AA, Alzhrani MA, Alkhathami AM, Mahfouza MEM. Prevalence of gastroesophageal reflux disease in Saudi Arabia. $J$ Clin Med Res. 2018;10(3):221-225. doi:10.14740/jocmr3292w

8. Almadi MA, Almousa MA, Althwainy AF, et al. Prevalence of symptoms of gastroesopahgeal reflux in a cohort of Saudi Arabians: a study of 1265 subjects. Saudi J Gastroenterol. 2014;20(4):248-254. doi:10.4103/1319-3767.136982

9. WHO Expert Committee. Obesity: preventing and managing the global epidemic. Report of a WHO consultation. World Health Organ Tech Rep Ser. 2000;894:i - xii, 1-253.

10. Fontaine KR, Barofsky I. Obesity and health-related quality of life. Obes Rev. 2001;2:173-182. doi:10.1046/j.1467-789x.2001.00032.x

11. El-Serag HB. Time trends of gastroesophageal reflux disease: A systematic review. Clin Gastroenterol Hepatol. 2007;5:17-26. doi:10.1016/j.cgh.2006.09.016

12. Friedenberg FK 1, Xanthopoulos M, Foster GD, Richter JE. The association between gastroesophageal reflux disease and obesity. Am J Gastroenterol. 2008;103(8):2111-2122. doi:10.1111/j.15720241.2008.01946.x

13. Jones R, Junghard O, Dent J, et al. Development of the GerdQ, a tool for the diagnosis and management of gastro-oesophageal reflux disease in primary care. Aliment Pharmacol Ther. 2009;30:1030. doi:10.1111/j.1365-2036.2009.04142.x

14. Ben Chaabane N, El Jeridi N, Ben Salem K, et al. Prevalence of gastroesophageal reflux in a Tunisian primary care population determined by patient interview. Dis Esophagus. 2012;25(1):4-9. doi:10.1111/des.2012.25.issue-1

15. Sharma PK, Ahuja V, Madan K, Gupta S, Raizada A, Sharma MP. Prevalence, severity, and risk factors of symptomatic gastroesophageal reflux disease among employees of a large hospital in Northern India. Indian J Gastroenterol. 2011;30(3):128-134. doi:10.1007/s12664-0100065-5

16. Saadi TA, Idris A, Turk T, Alkhatib M. Epidemiology and risk factors of uninvestigated dyspepsia, irritable bowel syndrome, and gastroesophageal reflux disease among students of Damascus University, Syria. J Epidemiol Glob Health. 2016;6(4):285-293. doi:10.1016/j. jegh.2016.07.001 
17. Delavari A, Moradi G, Birjandi F, Elahi E, Saberifiroozi M. The prevalence of gastroesophageal reflux disease (GERD) in the Islamic Republic of Iran: a systematic review. Middle East J Dig Dis. 2012;4(1):5-15.

18. Ho KY. From GERD to Barrett's esophagus: is the pattern in Asia mirroring that in the West? J Gastroenterol Hepatol. 2011;26(5):816824. doi:10.1111/j.1440-1746.2011.06669.x

19. Sharma MC, Sharma CK, Puri BP. Prevalence and the risk factors of gastro-esophageal reflux disease in medical students. Med J Armed Forces India. 2017;74(3):250-254. doi:10.1016/j.mjafi.2017.08.005

20. Karthik RC, Balaji SM, Arumugam B, Sriram RM, Ezhilvanan M. Prevalence of gastro esophageal reflux disease among medical students in Chennai, South India. Indian J Forensic Community Med. 2017;4(3):199-203.

21. Nam SY, Choi IJ, Nam BH, Park KW, Kim CG. Obesity and weight gain as risk factors for erosive oesophagitis in men. Aliment Pharmacol Ther. 2009;29:1042-1052. doi:10.1111/j.1365-2036.2009.03965.x

22. Jacobson BC, Somers SC, Fuchs CS, Kelly CP, Camargo CA Jr Bodymass index and symptoms of gastroesophageal reflux in women. $N$ Engl J Med. 2006;354:2340-2348. doi:10.1056/NEJMoa054391

23. Rey E, Moreno-Elola-Olaso C, Artalejo FR, Locke GR, Diaz-Rubio M. Association between weight gain and symptoms of gastroesophageal reflux in the general population. Am $J$ Gastroenterol. 2006;101:229-233. doi:10.1111/ajg.2006.101.issue-2

24. Lagergren J, Bergström R, Nyrén O. No relation between body mass and gastro-oesophageal reflux symptoms in a Swedish population based study. Gut. 2000;47:26-29. doi:10.1136/gut.47.1.26

25. Nilsson M, Johnsen R, Ye W, Hveem K. Lagergren lifestyle related risk factors in the aetiology of gastro esophageal reflux. Gut. 2004;53 (12):1730-1735. doi:10.1136/gut.2004.043265

26. Smit CF, Copper MP, van Leeuwen JA, Schoots IG, Stanojcic LD. Effect of cigarette smoking on gastro pharyngeal and gastro esophageal reflux. Ann Otol Rhinol Laryngol. 2001;110(2):190-193. doi:10.1177/000348940111000216

27. Murao T, Sakurai K, Mihara S, Marubayashi T, Murakami Y, Sasaki Y. Lifestyle change influences on GERD in Japan: a study of participants in a health examination program. Dig Dis Sci. 2011;56 (10):2857-2864. doi:10.1007/s10620-011-1679-x
28. Nandurkar S, Locke GR 3rd, Fett S, Zinsmeister AR, Cameron AJ, Talley NJ. Relationship between body mass index, diet, exercise and gastroesophageal reflux symptoms in a community. Aliment Pharmacol Ther. 2004;20(5):497-505. doi:10.1111/j.1365-2036.2004.02156.x

29. Chirila I, Morariu ID, Barboi OB, Drug VL. The role of diet in the overlap between gastro esophageal reflux disease and functional dyspepsia. Turk J Gastroenterol. 2016;27(1):73-80. doi:10.5152/ tjg.2015.150238

30. Khodarahmi M, Azadbakht L, Daghaghzadeh H, et al. Evaluation of the relationship between major dietary patterns and uninvestigated reflux among Iranian adults. Nutrition. 2016;32(5):573-583. doi:10.1016/j.nut.2015.11.012

31. Diaz-Rubio M, Moreno-Elola-Olaso C, Rey E, Locke GR 3rd, Rodriguez-Artalejo F. Symptoms of gastro-oesophageal reflux: prevalence, severity, duration and associated factors in a Spanish population. Aliment Pharmacol Ther. 2004;19(1):95-105.

32. Saberi-Firoozi M, Khademolhosseini F, Yousefi M, Mehrabani D, Zare N, Heydari ST. Risk factors of gastroesophageal reflux disease in Shiraz, southern Iran. World J Gastroenterol. 2007;13(41):54865491. doi:10.3748/wjg.v13.i41.5486

33. Locke GR 3rd, Talley NJ, Fett SL, Zinsmeister AR, Melton LJ 3rd. Risk factors associated with symptoms of gastroesophageal reflux. Am J Med. 1999;106(6):642-649. doi:10.1016/s0002-9343(99)00121-7

34. Zheng Z, Nordenstedt H, Pedersen NL, Lagergren J, Ye W. Lifestyle factors and risk for symptomatic gastroesophagealreflux in monozygotic twins. Gastroenterology. 2007;132(1):87-95. doi:10.1053/j. gastro.2006.11.019

35. Cameron AJ, Lagergren J, Henriksson C, Nyren O, Locke GR 3rd, Pedersen NL. Gastroesophageal reflux disease in monozygotic and dizygotic twins. Gastroenterology. 2002;122(1):55-59.

36. Bonfiglio F, Hysi PG, Ek W, et al. A meta-analysis of reflux genomewide association studies in 6750 Northern Europeans from the general population. Neurogastroenterol Motil. 2017;29. doi:10.1111/ nmo. 12973

37. Asling B, Jirholt J, Hammond P, et al. Collagen type III alpha I is a gastro-oesophageal reflux disease susceptibility gene and a male risk factor for hiatus hernia. Gut. 2009;58(8):1063-1069. doi:10.1136/ gut.2008.167353
International Journal of General Medicine

\section{Publish your work in this journal}

The International Journal of General Medicine is an international, peer-reviewed open-access journal that focuses on general and internal medicine, pathogenesis, epidemiology, diagnosis, monitoring and treatment protocols. The journal is characterized by the rapid reporting of reviews, original research and clinical studies across all disease areas. The manuscript management system is completely online and includes a very quick and fair peer-review system, which is all easy to use. Visit http://www.dovepress.com/ testimonials.php to read real quotes from published authors. 